\title{
Comment
}

\section{Trained to interact: echoes from the Workshop Sul- Americano de Mediação em Museus e Centros de Ciência}

\author{
Luisa Massarani, Paola Rodari, Matteo Merzagora
}

\begin{abstract}
The initiatives focusing the professional development of explainers are multiplying around the world, building an informal network of researchers, museums managers and directors, explainers, and regional/continental networks, as THE group, the Thematic Human Interface and Explainers group of Ecsite.

The "Workshop Sul-Americano de Mediação em Museus e Centros de Ciência e Escola de "Mediação em Museus e Centros de Ciência", which took place in Rio de Janeiro in September 2008, was a further important step along this path. We believe it is worthwhile to offer to Jcom readers some of the workshop contributions concerning the training of explainers, to which we added an overview of the general problem presented by Lynn Uyen Tran (Lawrence Hall of Science at the University of California, Berkeley).
\end{abstract}

On these electronic pages we already explored once the world of scientific explainers (see the commentary published in Jcom no. 4 2005). That collection was one of the first and still one of the few works at international level devoted to such a crucial, yet so overlooked, professional role: scarcely paid, scarcely trained and scarcely involved in the strategic or creative management of museums and science centres. Rather, somehow the problem was - and basically still is - that in fact the explainer has not become a "professional role" as yet." The word "explainer" indeed refers to a variety of operators widespread all over the world and in many contexts of science communications, but it still does not imply a precise definition, a set of features, a professional profile and a training path commonly shared. The word itself varies from country to country and even from museum to museum within the same country: "pilot, educator, demonstrator, presenter, etc." 2 To find back a common ground, it can be said that the job of an explainer is to be the direct interface between the institutions (museums, science centres, research institutes, festivals) and the public.

That first commentary coincided with the first steps taken by DOTIK, ${ }^{3}$ a project funded by the programme Scienz and Società del Sesto Programma quadro, which led to the first European summer school for explainers in science centres and museums, designed to outline a specialisation path for explainers inclined to dialogue-oriented and interactive activities. ${ }^{4}$

That occasion marked the creation of the first data collection on the situation in European science centres: the number of explainers employed, what their contract, what their career prospects, what their training, what their perception of their own role... It consisted of very elemental and scattered data, which above all allowed for the identification of difficulties in building quantitative maps of an extremely differentiated field and to compare very different situations. For example, there are cases in which either $0 \%$ or $100 \%$ explainers have a long-term contract; elsewhere, either the vast majority or minority of explainers have a scientific education.

DOTIK had in any case the merit of stirring things up in Europe and spurring the launch of new projects. At the same time, it promoted the opening of new channels to reach extra-European entities, building a network, yet informal and not structured, for an exchange of experience and reflections.

Starting from 2005, when the first session on explainers was organised at the annual conference of Eciste - European Network of Science Centres and Museums (www.ecsite.net) precisely in correspondence with the launch of DOTIK, the theme turned into one of the interests of the European association of science museums. Until the creation, in 2007, of THE group (Thematic Human interface 
and Explainers group), the first thematic group of Ecsite, having the purpose of gathering information and best practices at European level, of promoting the exchange among different institutions, and of boosting the professional development of explainers.

THE group then organised two training workshops for European science explainers, in 2007 in Lisbon and in 2008 in Budapest, ${ }^{6}$ and manages a website documenting the activities implemented and aims at functioning as a platform for the meeting and the exchange among explainers. ${ }^{7}$

The workshops were attended, as tutors or as participants, by explainers, researchers or managers from all over Europe, but also from United States, Malaysia, Yemen, thus creating a relevant network having an international dimension.

In the meantime, in Brazil, the Museu da Vida of the Fiocruz Foundation and of DOTIK published the first collection of essays on science explainers, ${ }^{8}$ which offered a further international dimension to the debate, as well as some cross yet very central themes as the role of museums in the social inclusion actions, or the intersections, not always clear and not always shared, between teaching and the science explainers' activity.

The Workshop Sul-Americano de Mediação em Museus e Centros de Ciência e Escola de "Mediação em Museus e Centros de Ciência”, which took place at the Museu da Vida of Rio de Janeiro in September $2008,{ }^{9}$ was a further important step along this path. There were so many issues dealt with over the six days of the workshop, and we believe it is worthwhile to sum up some contributions concerning the training of explainers. ${ }^{10}$

This is a crucial theme for a number of reasons. Indeed, the type of training that science centres and museums set up for their explainers is a mirror of the conception of their role in the institution. Starting from the lack of a real training (which is the case more frequently than expected, a clear sign of the lack of consideration of the explainers' role in determining the quality in a museum's activities), up to wellconstructed programmes that, aside from guaranteeing the qualification of the staff, turn the explainers' training itself into an occasion for communication and social inclusion. But also the type of training offered is an indication: more or less oriented towards practice, more or less integrated into the exhibition development process, more or less assessed as part and parcel of the professional tasks, internal or aimed at collecting external input, focussed on scientific contents or on the engagement techniques, and so on.

The contribution we would like to give to the debate is twofold: on the one hand, to share some practical examples and significant experiences. On the other hand, a debate on the importance of training to grasp the position of the explainers in the professional world rotating around science museums, and therefore to enhance the role of a figure contributing in a fundamental way to determine the quality of the offer of museums themselves.

Translated by Massimo Caregnato

\section{Notes and references}

\footnotetext{
${ }^{1}$ Aside from the articles in the Jcom collection 4(4), 2005, see also: E.B. Bailey (ed), The professional relevance of Museum Educators. Perspectives from the field. Journal of Museum Education, 31(3): pp.175-197; P. Rodari, M. Merzagora, F. Conti and F. Manzoli (2006), Beautiful guides - the role of professional explainers and young scientists in science and society dialogue. Proceeding of the PCST-9, 2006, Seoul (Korea), 17-19 May; L.U. Tran and H. King (2007), The professionalization of Museum Educators: The Case in Science Museum. Museum Management and Curatorship, 22( 2) pp.131-149. See also M. Merzagora and P. Rodari (2007a), La scienza in mostra, PBM Bruno Mondadori; A. Garlandini (2007). La carta nazionale delle professioni museali. Genesi, risultati, prospettive. Museologia Scientifica 1(1) pp.129-139; A. Love-Rodgers and B. Kelly (2001), A Survey on Explainer Management in Interactive Centres. BIG, September 2001

http://www.big.uk.com/knowledgebase/centres/download/explainer_report.pdf; C. Merola (2007), La comunicazione educativa tra operatori didattici museali e utenti nel corso delle visite guidate: indagine conoscitiva al Museo Civico di Storia Naturale di Verona. Museologia Scientifica 1(1): pp.90-96; M. Marino and J. Koke (2003) Face to Face: Examining Educational Staff's Impact on Visitors. ASTC Dimensions, January/February.

${ }^{2}$ In fact, there are many names for the same profession, and many professions under the same name. The list of names used across Europe for a scientific explainer makes up a tongue twister which embodies the idea of a tower of Babel at conceptual level, aside from at linguistic level. Concerning this theme see also P. Rodari and M. Merzagora (2008), Il volto umano dei musei. Gli animatori scientifici in Europa: numeri, pratiche e bisogni formativi, Museologia scientifica n. 2 second series.
} 
${ }^{3}$ The project was coordinated by the ICS research group of SISSA-ISAS of Trieste and involved three science centres as partners: Immaginario Scientifico Science Centre (Trieste, Italy), Hisa Eksperimentov (Ljubljana, Slovenia) e AT-Bristol Science centre (Bristol, GB). For more information http://www.dotik.eu.

${ }^{4}$ For a summary of the project results, see: DOTIK report, www.dotik.eu. See also P. Rodari, M. Merzagora, F. Conti and F. Manzoli (2006). Beautiful guides - the role of professional explainers and young scientists in science and society dialogue. Proceeding of the PCST-9, 2006, Seoul (Korea), 17-19 May; M. Merzagora, P. Rodari and F. Sgorbissa ( 2006). La formazione degli animatori scientifici. In N. Pitrelli and G. Sturloni (eds), Governare la scienza nella società del rischio. Atti del IV Congresso di Comunicazione della Scienza, Polimetrica.

${ }^{5}$ P. Rodari and M. Merzagora (2008), Il volto umano dei musei. Gli animatori scientifici in Europa: numeri, pratiche e bisogni formativi, Museologia scientifica n. 2 seconda serie

${ }^{6}$ THE group pre-conference, Lisbon, 30 May 2007. Dialogues: learning through discussions and conversations, Budapest, 27 May 2008.

${ }^{7}$ http://medialab.sissa.it/THE

${ }^{8}$ L. Massarani, P. Rodari and M. Merzagora (eds) (2007), Diálogos \& Ciência, Mediação em museus e centros de ciência. Museo da Vida, Rio de Janeiro.

${ }^{9}$ The programme and the speeches delivered at the workshop are available on: www.museudavida.fiocruz.br/mediador2008

${ }^{10}$ On the training of explainers, see also the poster collection presented during the session "Training to interact: how are interactive humans trained in science centres?" at the ECSITE annual conference in Lisbon, in 2007, available on-line in PDF format on the THE group website: medialab.sissa.it/THE. Still on the same subject see also: JOHNSON C. (2005), Training science center Explainers. The Techniquest experience. Jcom 4(4); M. Merzagora, P. Rodari and F. Sgorbissa (2006), La formazione degli animatori scientifici, in N. Pitrelli and G. Sturloni (eds), Governare la scienza nella società del rischio. Atti del IV Congresso di Comunicazione della Scienza, Polimetrica.

\section{Author}

Luisa Massarani is a Brazilian science journalist. Her doctoral degree was obtained at the Federal University of Rio de Janeiro. She works in both practical and academic activities. She coordinates the Nucleus of Studies on Science Communication of the Museum of Life/Oswaldo Cruz House/Fiocruz (Brazil) and the website SciDev.Net/Latin America and the Caribbean (www.scidev.net).

E-mail: lumassa@fiocruz.br.

How to CITE: L. Massarani, P. Rodari and M. Merzagora, Trained to interact: echoes from the Workshop Sul-Americano de Mediação em Museus e Centros de Ciência, Jcom 07(04) (2008) C01 